\title{
"This Large Household": Architecture and Civic Identity at the Iowa Hospital for the Insane at Mount Pleasant
}

\author{
JANE SIMONSEN
}

IN 1861 Richard J. Patterson, superintendent of the Iowa Hospital for the Insane, praised the as yet incomplete state asylum as a concrete symbol of the state's civic health and maturity. Just 15 years after Iowa became a state, Patterson wrote to Governor Samuel Kirkwood to assure him that the state was ready to measure itself by the extent of its civic philanthropy. Designed to serve the needs of a small fraction of the citizenry, the asylum, with its grand architecture, nonetheless functioned as a gauge of Iowa's ability to provide a haven for the mentally ill and to ease the burden of care on families, as well as an indication of the state's technological modernity. "The plan of the building was conceived on a scale of philanthropy worthy of a Great State," the asylum's first biennial report announced. "It was intended to embrace all the improvements, conveniences, and appointments requisite to promote restoration to soundness of mind in those persons bereft of reason, whose recovery may be hoped for; and to secure the comfort and happiness of those wretched beings ... whose mental alienation is irremediable and hopeless. When this vast structure is completed, such a Hospital for the Insane Iowa will have." By its mere existence, the hospital symbolized the progress of a state that had learned

THE ANNALS OF IOWA 69 (Spring 2010). (C) The State Historical Society of Iowa, 2010. 


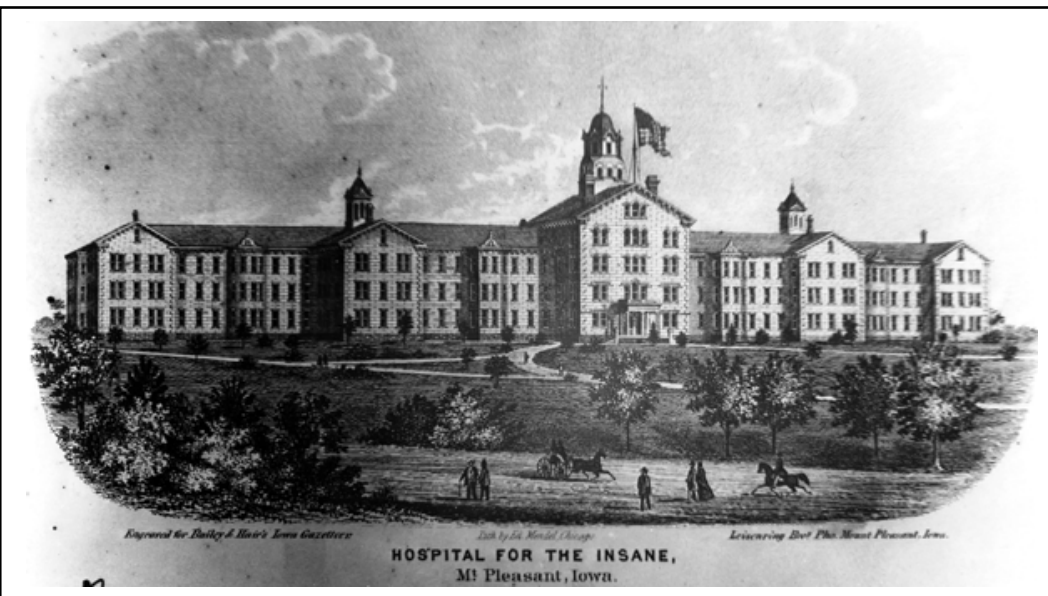

Figure 1. 1867 engraving of the Mount Pleasant Hospital for the Insane. Courtesy Iowa Wesleyan College Archives.

to "erect and dedicate an institution to the amelioration of suffering humanity"; it represented the artful combination of the technological and the beautiful; and it served the needs of patients for whom privacy, order, and an agreeable environment were central to their care. ${ }^{1}$

Although the colossal structure made a firm statement about Iowa's coming of age, the very need for such a building reflected uncertainty about what role various social and architectural spaces - cities, rural areas, public institutions, and especially private homes - played in shaping citizens. When the asylum opened to patients in 1861, it was the young state's grandest architectural undertaking, the "first permanent building erected in the state," according to one visitor's account. ${ }^{2}$ It was an enormous structure, with an ornamented façade, a sprawling east wing (the west wing would be completed in 1865), and a central rotunda with cupola rising nearly 140 feet above the Iowa landscape (fig. 1). Patterson and asylum superintendents of the succeeding decades thought of the asylum's architecture as both public and domestic: dedicated to the welfare of citizens yet

1. First Biennial Report of the Trustees, Superintendent, and Treasurer of the Iowa Hospital for the Insane at Mount Pleasant (Des Moines, 1862), 7, 15-23.

2. Burlington Hawk Eye, 3/9/1861. 
providing patients with the privacy, self-control, and moral instruction that were often associated with the home in the nineteenth century.

In spite of the specialized architecture and economic constraints of such an enormous, publicly funded building, superintendents regularly referred to the hospital as a "large household" and to those who worked and lived there as part of an extensive but "well-regulated family" that, like other families of the era, was meant to recognize the needs for individual integrity and for order within the household. Indeed, the wellregulated household was often invoked by nineteenth-century reformers, politicians, and domestic scientists as the incubator for social order and citizenship. Yet superintendents, policymakers, physicians, and patients at the Mount Pleasant asylum also recognized that the household was not an unproblematic place and was itself often the source of mental illness. The architecture of the Mount Pleasant asylum reveals ways that nineteenth-century Iowans understood the appeals and the limits of domestic architecture and of domesticity itself as they sought to improve upon it through technological, scientific, and moral means. The asylum's design incorporated the civic ideals of domestic life: morality, self-control, hard work, and orderliness based on proper categorization and lines of authority. At the same time, the emphasis on scale, utility, and scientific precision and professionalism tacitly acknowledged and even helped to construct the impression of the home's failure to provide an environment in which such ideals could be cultivated. Even as architectural changes to the asylum in the late nineteenth century seemed to valorize domestic architecture, "homelike" design became a gloss on a modernizing institution. ${ }^{3}$

LIKE MANY ASYLUMS built in the United States in the middle of the nineteenth century, the Mount Pleasant facility was deeply influenced by beliefs about the importance of hospital design in the treatment of mental illness. Practitioners of the "moral cure" that dominated psychiatric care in the United States and western Europe between 1830 and 1870 posited that

3. Third Biennial Report (1866), 14; Eighth Biennial Report (1876), 18. 
disorders of the brain were created by disorderly environments - from the stress and strain of urban living to the isolation of an Iowa farmhouse. Thus, the goal of asylum design was to create an environment that would calm and isolate the patient from such daily cares by implementing order, regimenting daily activities, and providing aesthetically beautiful and intellectually stimulating surroundings. ${ }^{4}$

The asylum's particular architecture helped to legitimate the professional status of psychiatric physicians, often called alienists, who claimed authority over this type of hospital. In 1844 they consolidated their professional identity in the Association of Medical Superintendents of American Institutions for the Insane (AMSAII). Because alienists considered the architecture of the asylum crucial to moral treatment, discussion of spatial design was prominent in the American Journal of Insanity, the voice of the AMSAII. Not long after its founding, the AMSAII organized a Committee on Construction, whose first major policy statement was a manifesto on the principles of asylum construction. Thomas S. Kirkbride, one of the AMSAII's original members and the superintendent of the Pennsylvania Hospital for the Insane, authored the "Propositions on the Organization of Hospitals for the Insane," which were adopted by the AMSAII in 1853, two years after the Iowa General Assembly authorized the sale of state lands to pay for the asylum at Mount Pleasant and two years before the state legislature voted to fund construction of the institution. ${ }^{5}$

Kirkbride's principles put into practice the theories of believers in moral management about the importance of hospital design for treatment. Among the propositions were the stipula-

\footnotetext{
4. On the "moral cure" and asylum design, see especially Ruth B. Caplan and Gerald Caplan, Psychiatry and the Community in Nineteenth-Century America: The Recurring Concern with the Environment in the Prevention and Treatment of Mental Illness (New York, 1969); David J. Rothman, The Discovery of the Asylum: Social Order and Disorder in the New Republic (New York, 1971); Gerald N. Grob, The Mad Among Us: A History of the Care of America's Mentally Ill (New York, 1994); and Nancy Tomes, The Art of Asylum-Keeping: Thomas Story Kirkbride and the Origins of American Psychiatry (Philadelphia, 1994).

5. Thomas S. Kirkbride, On the Construction, Organization, and General Arrangements of Hospitals for the Insane (Philadelphia, 1854), 6; Wesley Shank, ed., Studies of Historic Iowa Architecture, Part II (Ames, 1975), 1-2.
} 
tions that the building be easily identifiable as a civic landmark situated near a town; that every hospital be equipped with the latest in ventilation, heating, and water supply technology; that every hospital have eight wards for each gender for a total of 16 classes; that every room have a window; that the building include a central tower for administrative offices and residences; and that patients be housed in radiating wings suffused with light and air. All asylums should be surrounded, moreover, with "pleasure grounds" so that patients might exercise and be healed by strolls in a well-maintained and controlled "healthful, pleasant, and fertile" environment. The façade would create a sense of awe in patients, visitors, and would-be philanthropists even as the exterior ornamentation served another purpose: "to mask, as far as possible, by arrangements of a pleasant and attractive character," all signs of restraint that would make the building resemble a prison. While the exterior would nod to well-established principles of good taste, the inside needed to reflect alienists' concern with order; therefore, the interior spaces were designed with attention to utility, repetition of elements, accessibility, and the classification of patients that separated male from female, curable from incurable, and unruly from cooperative (fig. 2). ${ }^{6}$

The designers and backers of the Mount Pleasant asylum hewed closely to these principles, and their efforts reveal collaboration between state leaders and national authorities in hospital design. In 1855, following passage of the Act to Establish an Insane Asylum, asylum commissioners Edward Johnson and Dr. Charles S. Clark visited asylums in the East and consulted with Kirkbride as well as Luther V. Bell, a founding member of the AMSAII and superintendent of New Hampshire's McLean Asylum, one of the oldest in the nation. As a result of these visits, the board urged the state to fund a hospital that closely followed the comprehensive Kirkbride plan. Perhaps because legislators were interested in the ways such an asylum would brand Iowa as a progressive state, they seemed to be willing to listen to the AMSAII board, which urged them to reject a less ambitious plan to build a $\$ 50,000$ hospital that

6. Kirkbride, On the Construction of Hospitals for the Insane, 6-14. 

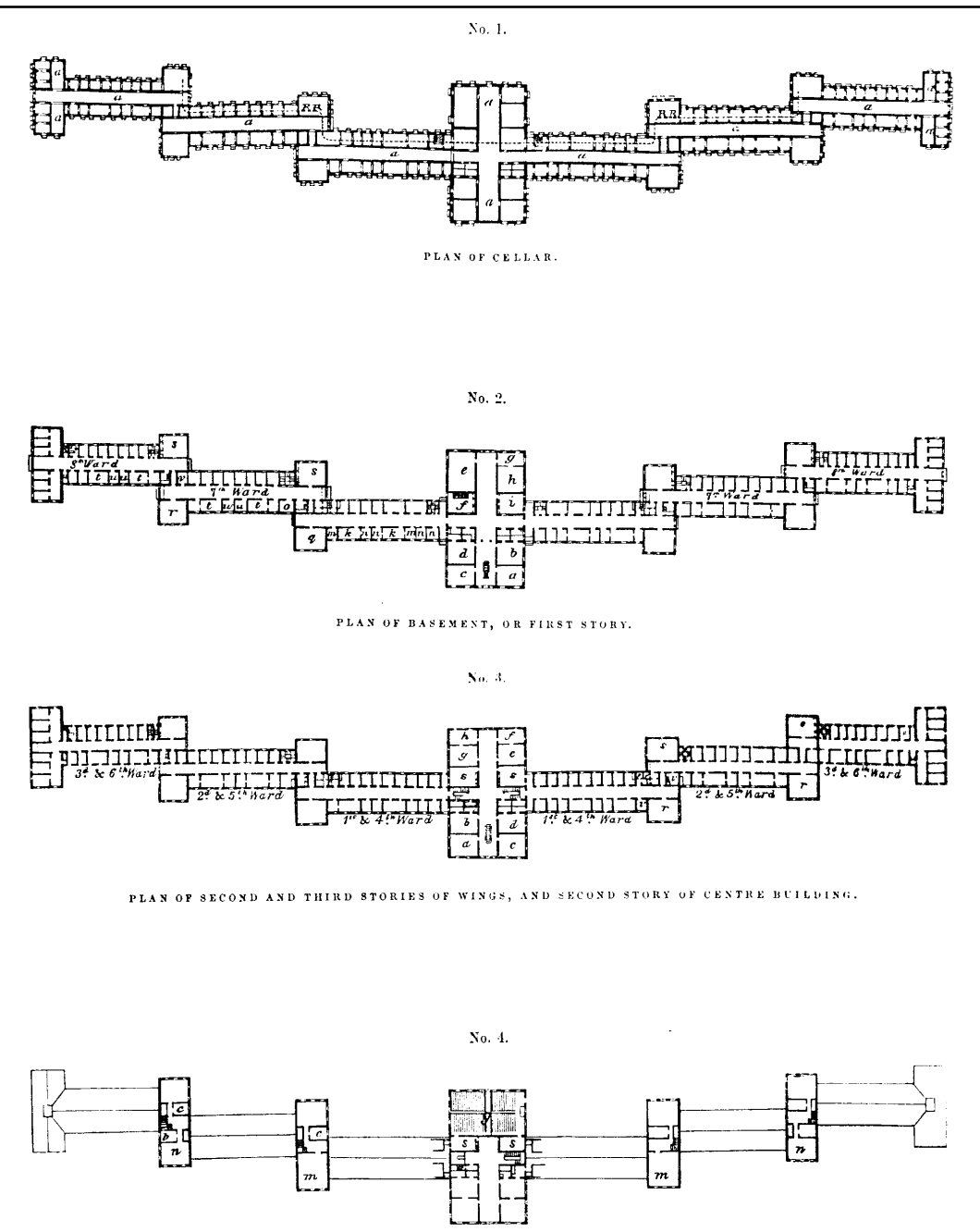

PLAN OF THIRD BTORY CENTRE BUILDING, AND PBOJBCTIONS OF WINGS.

Figure 2. Thomas Kirkbride's plan for a moral treatment facility, from American Journal of Insanity 11 (1854).

would fall far short of fulfilling alienists' architectural ideals. Bell offered an initial design, but the official architect of the Iowa hospital was Jonathan Preston of Boston, who designed the Northampton Lunatic Hospital in Massachusetts at about the same time. Mount Pleasant steward Henry Winslow worked 


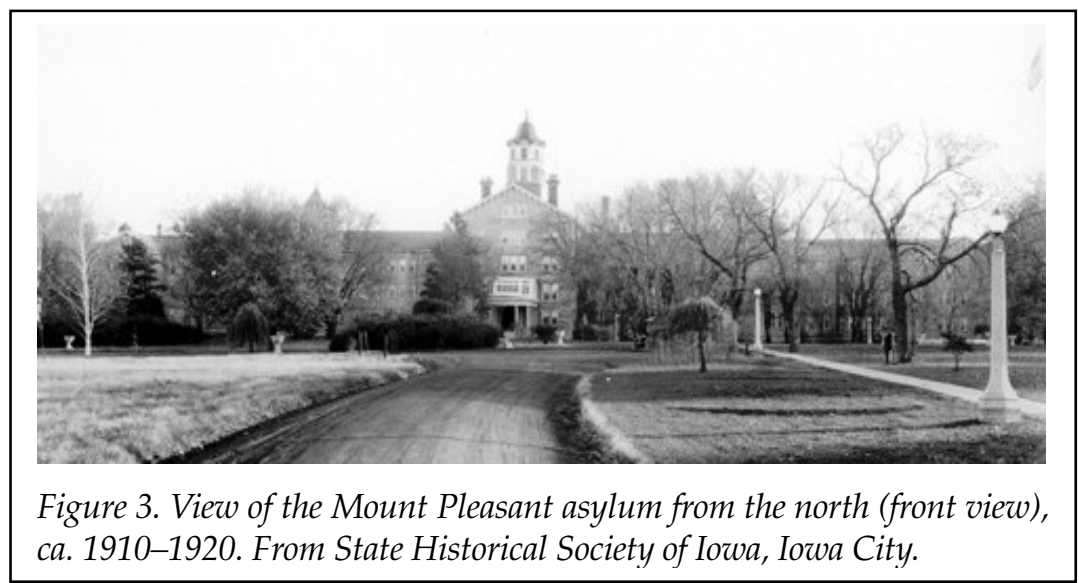

with the architect and board in adhering as closely as possible to the plan, even as, according to Patterson, he combined "architectural expression with greater practical utility." ${ }^{7}$

The Iowa facility was monumental. It was built just outside the city of Mount Pleasant, on a rolling landscape yet close to the supplies and labor power that the town offered, as Kirkbride had recommended. The revised, more ambitious plan called for 50,000 square feet in two three-story wings and a central building surrounded by pleasure grounds, in keeping with the AMSAII principles. Patterson, installed as superintendent in 1861, reported upon the asylum's opening that "instead of the long, lofty, meaningless pile of masonry, which we often see in similar structures, they have produced a building of rare dignity and beauty of proportion, agreeably diversified by bold projection and varied elevation." The style was "Elizabethan" with some features of Italianate detailing, including roof cornices, pediments, and cupolas. The windows of the central building had a slight Palladian curve, but most windows were topped with simple rectangular lintels. The ornamentation emphasized size and repeated elements rather than variety, and its variations were those of degrees of elevation and diversity in the façade due to bay windows and recesses (figs. 3, 4). Bell recommended this style, also described as "Tudor Gothic," because it was nei-

7. History of Henry County, Iowa (Chicago, 1879), 434; Shank, Studies, 3-5; First Biennial Report (1862), 15. 


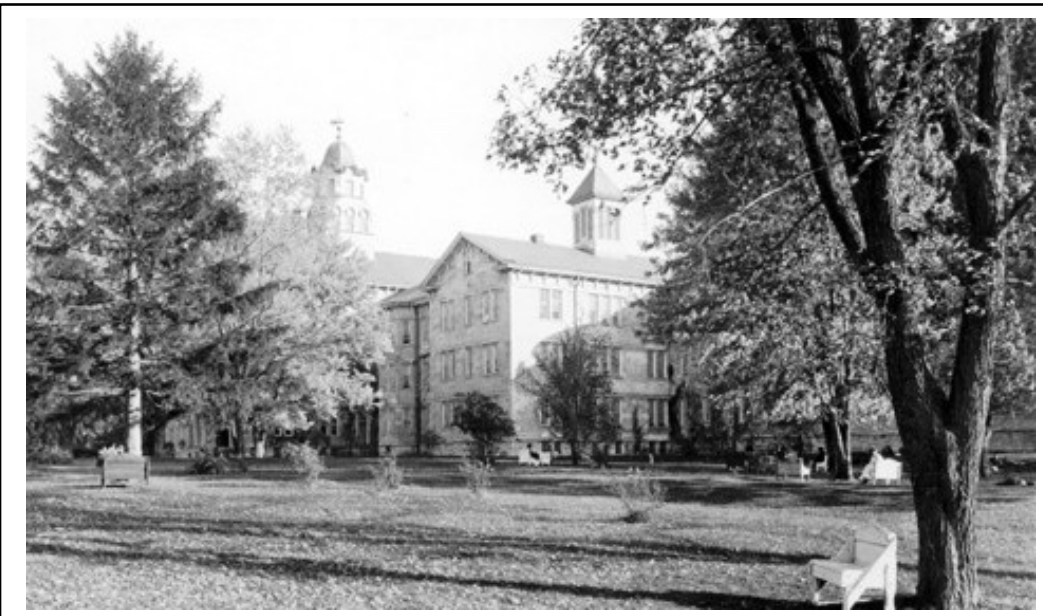

Figure 4. View of the Mount Pleasant asylum from the east, ca. 1910-1920. From State Historical Society of Iowa, Iowa City.

ther too decorative nor too plain and imposing. His ideas were both aesthetic and practical, as he was (as were all superintendents) intent on keeping expenses down, especially in developing states. Thus Bell's encouragement that "the amount of stone needed to produce the proper effect in this style is not great." ${ }^{8}$

Inside, the building proclaimed the importance of central control and orderliness on a grand scale. The building was designed around a soaring rotunda and cupola with a double stairway inside (fig. 5). The rotunda housed the offices and rooms of all resident officers, including the superintendent, steward, and matron. Behind the rotunda stretched the facilities such as the kitchen, laundry, and chapel. The basement contained an eighth-mile "railroad" to carry food to dumb waiters as well as the equipment for steam heating the entire building. The building was also equipped for gas lighting and had tech-

8. First Biennial Report (1862), 16; Shank, Studies, 13; Luther V. Bell, “To the Trustees of Butler Hospital for the Insane," American Journal of Insanity 2 (1845-46), 31. Patterson was formerly at the Indiana State Asylum, and his choice to head another public institution is interesting given that he wrote to Kirkbride in 1852 that "these state institutions are horrible establishments, and no sensitive man - none but one who has the skin of a RHINOCERUS has any business in one of them." Apparently Patterson had developed a thick skin in the intervening decade. Tomes, The Art of Asylum-Keeping, 276. 


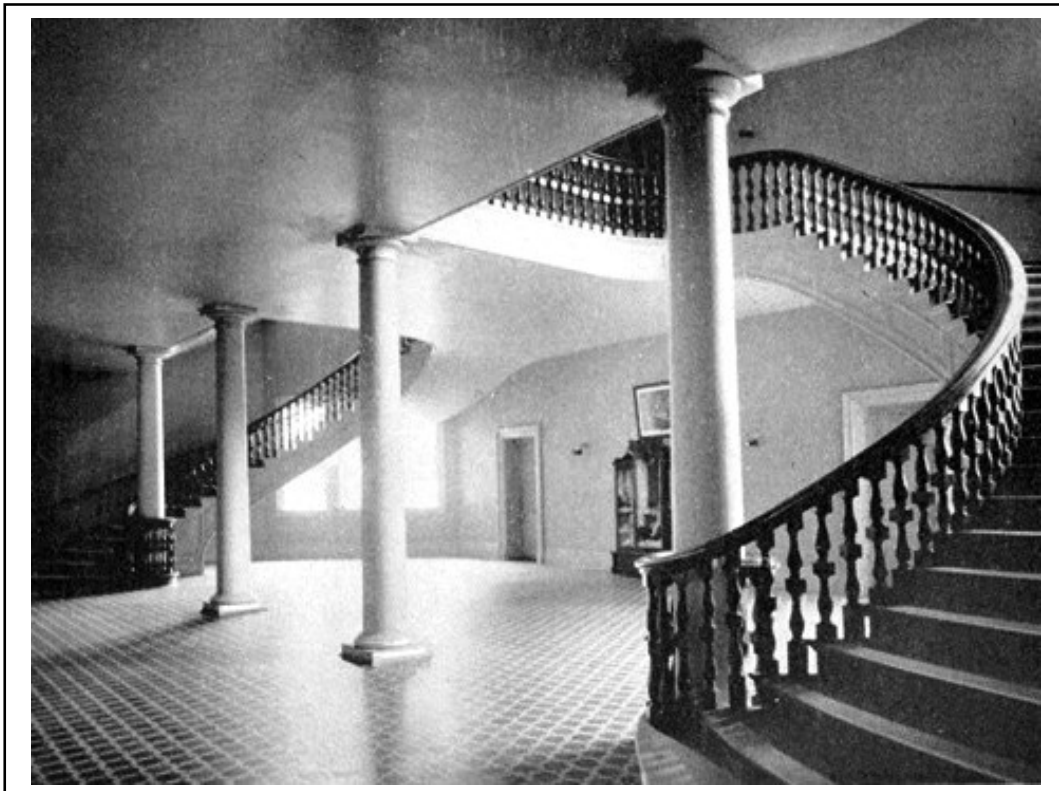

Figure 5. Rotunda with staircase, 1897. From State Historical Society of Iowa, Iowa City.

nologies for ventilating all the rooms with windows, flues, and steam-driven fans. Only one wing was completed in 1861 when the asylum opened, but it was intended that the three-story wings, when completed, would contain 220 single rooms, 18 dormitories, 18 parlors, 18 dining rooms, 24 bathrooms, 24 water closets, 24 washrooms, and 78 closets. The building's wings were designed to accommodate the crucial environmental principle of categorization: separating men from women and the more difficult or incurable cases from the milder cases - the more compliant cases being placed in the more comfortable "bourgeois" wards closer to the central rotunda."

Early viewers of the asylum were certainly impressed by its scale and saw the building as Patterson and others hoped: upon the opening of the asylum on March 6, 1861, the Burlington Hawk

9. First Biennial Report (1862), 17. The Northampton hospital, also designed by Preston, closely resembles the Mount Pleasant asylum; its plans are reproduced in Carla Yanni, The Architecture of Madness: Insane Asylums in the United States (Minneapolis, 2007), 66. 


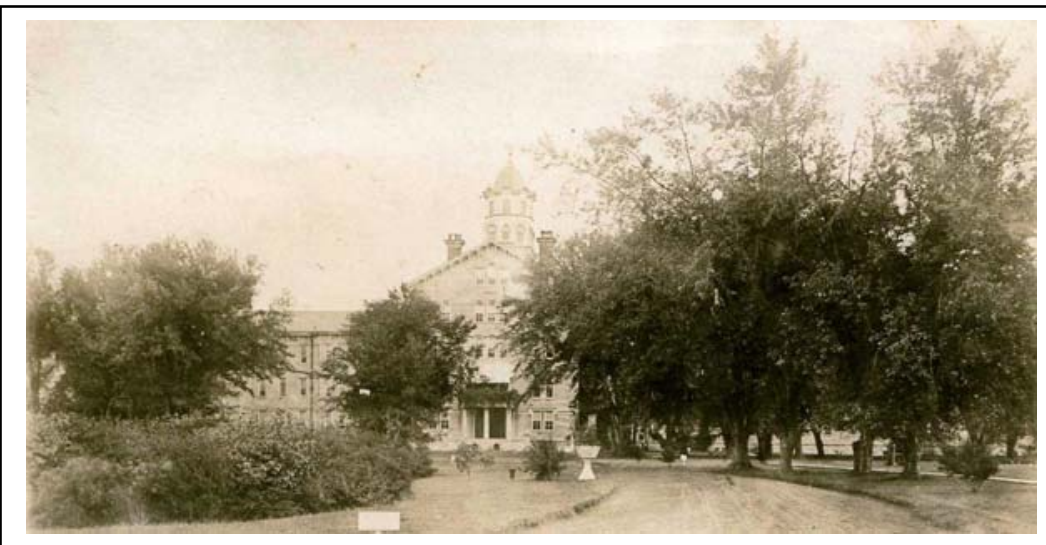

Figure 6. Postcard, Mount Pleasant Asylum. Courtesy Iowa Wesleyan College Archives.

Eye reported that "Mount Pleasant turned out en masse" and that "the Institution is an honor to the State, and will stand an imperishable monument to the skill, business capacity, faithfulness, and probity of Mr. Winslow." The author went on to invite readers to visit, as they would "find it a very pleasant place to spend an hour or two, and, notwithstanding its grated windows, and unfortunate inmates, having a cheerful, orderly and happy look." Viewers noted that in terms of technological innovation, no household could compare to the hospital. Visitors to the asylum were privy to the mechanisms that ran the large household; one visitor wrote, for example, that "the kitchen and cooking department in the cellar, is really a sight, and the eyes of lady visitors generally open pretty wide when conducted through this part."

The asylum's specialized design included the surrounding grounds as well, also regarded as key to moral and thus mental health: "If there is a spot on earth which ought to be improved and beautified by art, at the public expense, surely it is the one that surrounds the hospital for the Insane," Patterson exhorted the legislature in 1861. The surrounding landscape, designed by landscape architect H. W. Cleveland and completed in 1871, was intended to allow patients to stroll the grounds as on a country

10. Burlington Hawk Eye, 3/9/1861; Birmingham Enterprise, 4/1/1871. 


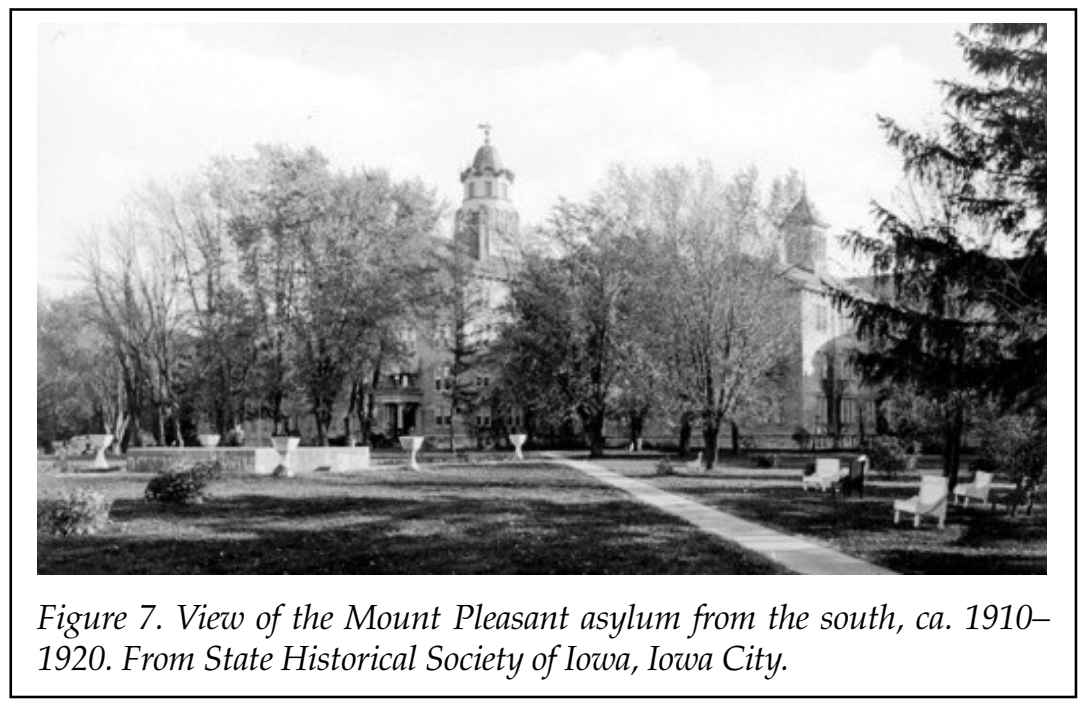

estate. Moreover, the windows afforded pleasing views of the surrounding landscape, which administrators hoped would provide patients, family members, and even residents of Mount Pleasant with "pleasant scenery, affording views as varied and attractive as any to be found in this part of the state." The model of the country home set in private pleasure grounds - the original blueprint of private asylums such as Kirkbride's Pennsylvania hospital - became, under the doctrine of moral treatment, infused with a kind of moral restraint ${ }^{11}$ (figs. 6, 7).

THE IOWA GENERAL ASSEMBLY'S 1855 decision to fund a state hospital for the insane built according to Kirkbride's principles both responded to and helped to create the public perception that the state and its appointees were ready to care for the mentally ill and to protect the public weal. Part of the process of state-building involves creating new social welfare policies and the institutions that would function as the visible manifestation of such policies. The asylum represented Iowa's attempt to establish new forms of state authority as well as superintendents' claims to professional authority. The kind of authority that asylums represented in the nineteenth century has been

11. First Biennial Report (1862), 10; Sixth Biennial Report (1872), 35-36. 
contested among historians who debate whether mid-century asylum design was a humanitarian response to social needs, a form of repressive custodialism reflecting superintendents' quest for social power, or states' attempts to suppress society's "unruly" members. ${ }^{12}$

Yet a dichotomy between control and care cannot fully account for the layers of meaning that asylums took on for different populations; instead, asylum architecture was a product of what Carla Yanni calls the very "tensions between home and institution, benevolence and surveillance, medical progress and social control, nature and culture" that shaped American society in general during the last half of the nineteenth century. The principles of asylum organization - and deviation from those principles - endorsed particular kinds of spaces as fundamental to moral and psychic health and exemplified ideal relationships among citizens, communities, and the state. The Mount Pleasant asylum's architecture, then, was the product of negotiations among representatives of larger cultural ideals. State officials, superintendents, hospital workers, and even patients regarded the Mount Pleasant asylum in ways that reveal the

12. According to John Sutton, "The Political Economy of Madness: The Expansion of the Asylum in Progressive America," American Sociological Review 65 (1991), 665-78, asylums and other public institutions tended to grow faster in newer states with an interest in establishing new systems of political and social order. For theories of benevolent intentions, see Albert Deutsch, The Mentally Ill in America: A History of Their Care and Treatment from Colonial Times, 2nd ed. (New York, 1949); and Grob, The Mad Among Us. For social control theories, see Erving Goffman, Asylums: Essays on the Social Situation of Mental Patients and Other Inmates (New York, 1961); Rothman, The Discovery of the Asylum; Andrew Scull, ed. Madhouses, Mad-doctors, and Madmen: The Social History of Psychiatry in the Victorian Era (Philadelphia, 1981); and idem, The Insanity of Place/The Place of Insanity: Essays on the History of Psychiatry (New York, 2006). Studies stressing complexity include Tomes, The Art of Asylum-Keeping; Ellen Dwyer, Homes for the Mad: Life Inside Two Nineteenth-Century Asylums (New Brunswick, NJ, 1987); Constance M. McGovern, Masters of Madness: Social Origins of the American Psychiatric Profession (Hanover, NH, 1986); idem, "The Myths of Social Control and Custodial Oppression: Patterns of Psychiatric Medicine in Late Nineteenth-Century Institutions," Journal of Social History 20 (1985), 323; Peter McCandless, Moonlight, Magnolias, and Madness: Insanity in South Carolina from the Colonial Period to the Progressive Era (Chapel Hill, NC, 1996); and Danielle Terbenche, "'Curative' and 'Custodial': Benefits of Patient Treatment at the Asylum for the Insane, Kingston, 1878-1906," Canadian Historical Review 86 (2005), 29-52. 
tensions between belief in the power of domestic spaces to cultivate individual virtues and the power of public architecture to rejuvenate citizens through more healthy work and gender roles than those offered by the home. ${ }^{13}$

In Iowa's case, early descriptions of the asylum in the biennial reports to the legislature accentuate features of the asylum that would help preserve civic order by removing disruptive elements from society. For example, Governor Grimes, appealing to the Fifth General Assembly in 1855, stressed the importance of the asylum in separating out destructive individuals. He seemed to invoke fear as well as reason, stressing that "there are now more than one hundred pauper insane persons in the State." While half were in jail, "the other moiety are remaining at large, a terror to their friends and neighbors, and by exposure to exciting causes, rendered their disease hopelessly incurable." Grimes cleverly suggested that current, less authoritative institutions such as city jails and families were inadequate to house this population even as he argued for the need to contain these persons through the restraining power of a state institution. While asylum design was a key to treatment, it also visually reinforced the authority of the state. The vastness of the asylum, combined with the emphasis on the entry and rotunda, denote "stability" in their very form. ${ }^{14}$

The asylum's design also stressed the professional authority of the steward, the matron, physicians and nurses, and especially the state-appointed superintendent. The physical location of their offices in the rotunda denoted in architecture the need for a superintendent who could survey the activities of all of his patients. He needed to be inside the building, for the superintendent was not just a doctor, but the head of a household of dependents. Superintendent Mark Ranney, who directed the asylum between 1865 and his death in 1882 (with the exception of two years spent at Wisconsin's state hospital in Madison), stressed the need for both professional authority and careful design when he wrote in 1876 that "if insanity were only a bodily disease ... the hospitals specially devoted to its treatment would

13. Yanni, Architecture of Madness, 1.

14. History of Henry County, 434; Yanni, Architecture of Madness, 52. 
be unnecessary. ... But insanity differs from most other diseases. Not only is the brain involved and disordered in its action, but through it the mind also, rendering the individual generally incapable of management by the ordinary methods applicable to the management of the sick." In fact, Ranney described the efforts of medical personnel as almost heroic in avoiding "serious accident or epidemic" and "collision and violence" among patients. Such results could only be achieved, he stressed, by adhering carefully to the "rules that governed the household" the AMSAII-endorsed design principles - which valued separation, order, and surveillance.

Part of the superintendents' authority rested in their ability to categorize patients according to principles of their own devising. Those principles were developed from popularly held beliefs, such as those about gender differences, but made those distinctions explicit through careful design. The merely nervous, for example, or those suffering from excitements due to novel reading or economic woes were separated from the more threatening patients; and the violent and the criminally insane, Superintendent Ranney argued, were best consigned to other spaces entirely. The Mount Pleasant asylum's careful separation of genders and cases both inside and outside the structure created a more orderly way of defining social and gender relations than existed in homes. In making those categories structural, the hospital's design made private dysfunction visible and suggested that living environments were both cause and cure of mental illness. The state, the structure pronounced, could provide the environment and care that would remedy - or at least remove such cases. ${ }^{16}$

15. History of Henry County, 437-38; Sixth Biennial Report (1872), 15. For biographical information on Ranney, see "Obituary," American Journal of Insanity 38 (April 1882), 465.

16. Ranney would have preferred that cases involving irremediable mental illness not be housed in the asylum at all. He felt that those who were "vicious, dangerous, and violent," "have delusions and hallucinations," or were "addicted to masturbation" did not even fit the accepted definition of insanity. He protested that the hospital was not built for security (one patient escaped even as Ranney was writing the ninth biennial report) but for moral cures, and such patients were generally incurable. If necessary, Ranney argued, such cases should be relegated to a separate building. History of Henry County, 439. 
The separation of classes and genders extended outside the asylum walls. Throughout the 1870s, Ranney continued to ask for funds to improve the grounds not only for the aesthetic pleasures of a varied landscape and the healthful benefits of agricultural work, but because the classification of patients needed to be maintained even outside the walls. Grounds were divided by walls or shrubs to maintain separation between patients, giving them freedom to enjoy nature within secure enclosures (fig. 4). The separation of the sexes and attention to perceived gendered differences in interactions with nature prompted the creation of groves in the garden as secluded nooks for female patients. ${ }^{17}$

The categories of mental illness that the hospital's design mapped out may have helped Iowans define the problems faced by their family members, encouraging families to identify as unacceptable behaviors that may once have been tolerated or treated within the confines of the home. Physicians' records at various public and private asylums indicate that families played a significant role in diagnosing patients' illnesses as they were admitted. Among Mount Pleasant's patients, masturbation, sexual aggressiveness, general ill health, business failings, and puerperal condition (ailments related to female reproduction) were all listed as causes of mental illness. These causes suggest what families saw as incorrect behavior. At the same time, asylum architecture, organized as it was according to various classes and conditions, helped direct understandings of what kinds of behaviors were most and least problematic. For example, the building's architecture was less fanciful than Gothic or elaborately ornamented Elizabethan styles, for the superintendents believed that one of the causes of insanity was literary life, the reading of Gothic novels, the "free indulgence in vapid amusements, [and] the reading of trashy romances." ${ }^{18}$

In particular, the asylum's architecture responded to and helped designate gendered behaviors as morally right or wrong.

17. See Sixth Biennial Report (1872) and Seventh Biennial Report (1874) on the design of the surrounding landscape.

18. Tomes, The Art of Asylum-Keeping, 114; Lindsay Prior, "The Architecture of the Hospital: A Study of Spatial Organization and Medical Knowledge," British Journal of Sociology 39 (1988), 90; History of Henry County, 442; First Biennial Report (1864), 23. 
When families identified problems such as sexual excesses, depression caused by business failings, overexcitement due to reading, or "female maladies" as mental illness, they were pinpointing problems of home life. When home failed to provide for men a respite from the marketplace, or when the lack of organization and privacy in the home contributed to women's exhaustion, mental illness could ensue. By organizing the asylum to reflect categories from the slightly depressed or hysterical to the dangerously violent, superintendents helped to legitimate such concerns. Moreover, they helped justify mental illnesses as gender dependent, as, for alienists, maladies often stemmed from the separate work and social environments of men and women that were intrinsic to family organization.

The asylum's design thus simultaneously identified patients as victims of the gender order and attempted to recuperate them to proper middle-class gender roles through regulated spaces and activities. One of the early concerns of hospital superintendents was that the failure to complete the west wing (the women's wing) threatened careful classification and separation of patients. By 1871, Ranney was lobbying for a separate building for women. In addition, those patients who were able to work engaged in separate activities, with the men assigned to construction activities such as improving the grounds and women assigned to interior activities such as laundry and sewing linens for the asylum itself. ${ }^{19}$

But Ranney's concerns about categorization inside and outside the asylum illustrate the degree to which his professional authority could be jeopardized by the state's power to allocate funds and to dictate the asylum's role in serving mentally ill citizens. Part of the difficulty of maintaining moral treatment was purely structural: as the asylum aged, the trustees sought funds to build new sewers, rehabilitate a ventilation system, shore up sinking foundations, repair leaky "water closets," bolster shrinking floorboards with brick arches and iron girders, and replace plaster walls between patients' quarters that were so thin that the more violent inhabitants could break through

19. Benjamin Reiss, "Letters from Asylumia: The Opal and the Cultural Work of the Lunatic Asylum, 1851-1860," American Literary History 16 (2004), 11; Sixth Biennial Report (1872), 17. 
them. The difficulties of fixing these deficiencies were exacerbated by the high cost of labor and materials and the scarcity of funding during the Civil War era when many of the problems first surfaced. ${ }^{20}$

At least as pressing as structural flaws was the overcrowding that endangered design from the start. For a building whose successful use was predicated on precise calculations of the space needed for each patient, rooms devoted to particular mental and physical functions, and separation of spaces, overcrowding was a design disaster. Before the women's wing opened, patients were crowded into one wing, making it impossible to adhere to rules governing classification. Ten years after the asylum opened, parlors, reading rooms, and even corridors had been appropriated as living quarters, a move that threatened "social, orderly, and appropriate arrangements." Ranney and others were angered by the number of chronic cases consigned to them by the state, as that practice changed the atmosphere of the hospital from that of a retreat to one that resembled the prisons and poorhouses they strove not to replicate. State policies created a nightmare for superintendents bent on classification: criminal, foreign, chronic, and poverty-stricken insane created more categories of insanity whose differences needed to be echoed in architecture. The state's power to designate who could reside at the hospital threatened the authority that superintendents sought to validate through design, while state-created categories whittled away at the medicalization of mental illness that superintendents fought for. ${ }^{21}$

One of the ways that leaders of the Mount Pleasant asylum sought to build professional authority, then, was by setting the physical and moral architecture of the asylum over against that of the private home. While the asylum was meant to be "homelike" in its care, capitalizing on the still powerful ideals of domesticity, it nonetheless identified the home as a cause of mental illness, and the asylum's monumental architecture suggested its distance from the home. The very architecture of many asylums was paradoxical, as "domestic" interiors coexisted with

20. For listings of structural problems, see Third Biennial Report (1866) and Sixth Biennial Report (1872).

21. Sixth Biennial Report (1872), 14. 
monumental, public exteriors. Indeed, for those who worked and stayed at the Mount Pleasant asylum, home and asylum were not so distinct from one another. The asylum could function as a home, and home as a repressive institution; the home could also provide respite from the asylum as a busy, disordered, and exhausting place. ${ }^{22}$

From the start, the Mount Pleasant asylum's design cast doubt on the nostalgic ideal of the independent settler's rural home by identifying it as the culprit. Superintendent Patterson wrote in 1863 that "it will seem strange that among the rural population of Iowa, . . . while quietly engaged in the peaceful pursuits of agriculture, any considerable number of people ... , especially the wives and daughters of farmers, become insane." ${ }^{23}$ Patterson was both responding to citizens' diagnoses of their own family members and stressing that the private family home, far from a refuge, was a restrictive environment, particularly for women who were least able to leave it. He stressed that women on the farm were removed from social and physical entertainments and confined to homes that were less than technologically modern - they suffered from poor ventilation and heating and desolate surroundings.

In some ways, then, alienists such as Patterson participated, along with nineteenth-century household theorists from Catherine Beecher to Charlotte Perkins Gilman, in the larger critique of households as repressive and unenlightened. Long before Betty Friedan identified "the problem that has no name" in 1963, material feminists of the mid-nineteenth century argued that the poor design of homes was partially responsible for women's social repression. By redesigning the home itself for efficiency (in the case of Beecher) or more radically (in the case of Gilman) to eliminate those features of the home that trapped women in unending rounds of household labor, these feminists argued that social, political, and economic power for women began at home. By the later decades of the nineteenth century, some feminists were criticizing domesticity itself as fundamentally repressive - that political power could come only through

22. Yanni, Architecture of Madness, 55.

23. Second Biennial Report (1864), 24. 
economic and social power gained outside the home, through professional work and wage labor. Rather than a bastion of morality and font of civic identity, the home, many social reformers argued, was more often a repressive, premodern, fundamentally limiting institution in need of radical change. These female reformers continued to see the home as a place that could become modern, though, through better technology, efficiency, and a broader understanding of the roles of women. ${ }^{24}$

Rather than advocating change in the home itself or through broader roles for women, however, Patterson lauded the asylum as a social, moral, and architectural alternative to the home, where, in Iowa, "the wives and daughters of farmers" were particularly susceptible to mental illness due to poor home construction and limited social opportunities. This echoes a larger late nineteenth-century phenomenon: even as the nineteenthcentury "cult of domesticity" was being celebrated as the foundation of an orderly society, state governments and philanthropic institutions were also encouraging the movement of some of the order-making mechanisms of the home - including health care - to institutions. Industrial schools, settlement houses, reformatories, hospitals, and asylums adopted many of the ideals of domesticity but took on the function of teaching those ideals in state-sponsored and professional settings. ${ }^{25}$

Patterson's and Ranney's reports highlight the state's ability to do what the family could not. In his 1876 report, Ranney appealed to the board of trustees for increased funding by explaining that mental illness implied a need for care that could not be met by families, and that attempts to care for such individuals at home could actually worsen the situation: "the insane person's own will and power of self-control being perverted or destroyed, the will of others must be substituted instead, and that often for months and years. It was long since found by experi-

24. On material feminism, see Dolores Hayden, The Grand Domestic Revolution: A History of Feminist Designs for American Homes, Neighborhoods, and Cities (Cambridge, MA, 1981).

25. Second Biennial Report (1864), 24-25. On the institutionalization of domesticity, see Laura Wexler, "Tender Violence: Domestic Photographs, Domestic Fictions, and Educational Reforms," in Laura Wexler, Tender Violence: Domestic Visions in an Age of U.S. Imperialism (Chapel Hill, NC, 2000). 
ence that generally the will or judgment of others than those of the patient's own household and kin could be beneficially substituted." Ranney justified the asylum as a "modern" hospital - and legitimated the expenses associated with it - by arguing that the need for the asylum arose directly from families' inexpert care for the mentally ill. ${ }^{26}$

Most prominently, the asylum's imposing design and scale signaled its difference from home life by highlighting organization and control. For example, the building's scale and central placement of administrative offices in the rotunda differed from the single-family home. Separate rooms for various activities such as sleeping, eating, socializing, and working made visible the "moral regimen" of treatment plans and showed families how patients would be encouraged to regulate themselves under the supervision of a host of hospital personnel - a feat difficult for the typical wife and mother to achieve (fig. 8). More so than any private home, the hospital was able to dedicate many rooms to specific physical functions: rooms to eat, wash, receive treatment, sleep, pray, be entertained. This emphasized the asylum's ability to control patients' various activities based on the rooms designed to accommodate them. The remedy for a disordered home life lay in creating a stable, regulated environment and scheduled activities that healed through "the change of scenery and associations; change of habits of life." ${ }^{27}$

BUT FOR WOMEN who worked and lived at the asylum, the lines between home and work may have been more permeable than Patterson and his successors implied. Former Civil War nurse Rhoda Amanda Shelton, who kept a diary during her tenure as asylum bookkeeper in 1866, regarded the asylum as both home and workplace. She describes late nights spent working with Ranney or his wife, Catherine, the matron; visits from the board of trustees to inspect her accounting work; "reading aloud to the ladies"; and her work with a women's sewing class. Her own office space likely legitimated her work, and Ranney signified his esteem by giving her keys to the wom-

26. Tomes, The Art of Asylum-Keeping, 114, 127; History of Henry County, 438-39.

27. First Biennial Report (1864), 30; Prior, "The Architecture of the Hospital," 105. 


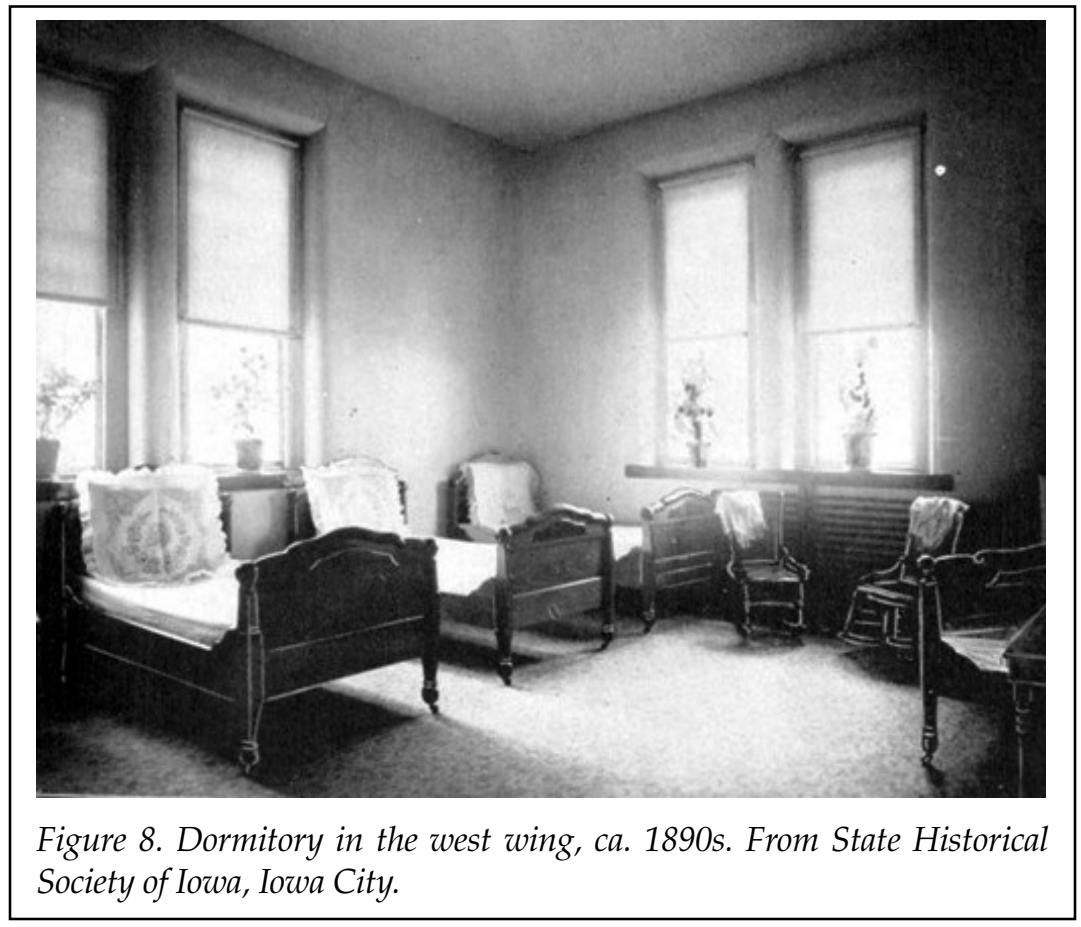

en's ward. "I have keys to the Ladies side of the house," she announced in her diary - access to space, in this case, was a way of signifying professional responsibility. "My visits to the wards are always a source of great pleasure to me," she wrote, and the patients' appreciation of her was "gratifying for I feel my life is not quite useless." Interestingly, Shelton identifies her interactions with patients as satisfying, while she describes her bookkeeping as a source of some anxiety. ${ }^{28}$

But her status as worker blends into her personal life, for the asylum was also her home. She documents social relationships with supervisors, ward attendants, and even patients. Although the wards where the "excitable" patients were kept distressed her, she visited patients in their parlors, reading and sewing with them, and attended evening dances with patients. She also regarded the grounds as an extension of home space, frequently

28. Sharon E. Wood, "'My Life Is Not Quite Useless': The 1866 Diary of an Asylum Bookkeeper," Palimpsest 70 (1989), 11-12. 
gathering flowers for the wards or playing croquet. Her work seems to have given her both professional and personal purpose, while her interactions with patients also seem to have affected her deeply. She "went to the window and looked up into the 'starry deep' and thought of the concentrated agony in this house," she wrote one evening - following her ruminations with the note that "I am learning to play croquet - play chess with Miss Bell quite frequently." Her diary moves almost seamlessly from the patients' social and living spaces to her own, from the disorder and distress of the wards to the peacefulness of her own quarters and social interactions. The walls of the asylum serve to hold in the "concentrated agony" of the mentally ill who were unable to function in society even as they provided a homelike refuge in which Shelton could cultivate her professional identity and her personal relationships. ${ }^{29}$

Coworkers were her confidantes, but patients were also members of her social circle. They attended dances together and even spoke intimately together, indicating that Shelton was touched as well affirmed by hearing the stories of patients, who ranged from mothers who had suffered breakdowns to a former attorney general of the state. Shelton often entered the wards to socialize with patients, but she also documents at least one case in which a patient visited her: "This morning as I sat in my Office writing Mr. Clark - the patient who brings me flowers so often - came in with a bouquet and a paper basket that would hold a quart, full of blackberries." For Shelton, the asylum's scale and diversity may have provided a freedom to move around social spaces that were more difficult for women to cross in public, as "home" and "work" both took place in the asylum's microcosm of society.

Perhaps because the asylum may have provided an empowering space for women like Shelton who worked there, women physicians tended to share the ideas of alienists that the causes of mental illness for women were primarily environmental. Like Patterson, Jennie McCowen, a graduate of the University of

29. Ibid., 9-10. Wood points out that Shelton was also recovering from her own distress: she had lost her brother in the Civil War and faced the horrors of battle herself while serving as a nurse during the war. Ibid., 3.

30. Ibid., 10 . 
Iowa's College of Medicine who became the women's physician at the Mount Pleasant asylum in 1875, claimed that the causes of illness for many women were their homebound lives, their "monotony of work and thought," and their lack of access to the spaces and freedoms that men enjoyed. On the other hand, McCowen's predecessor in the position, Margaret Abigail (Abbie) Cleaves, who was hired as the asylum's first female physician in 1873 (only the second woman in the nation to be hired in such a capacity), acknowledged the pressures of environment in mental illness even as she averred that "true neurasthenes [the condition from which she herself suffered] are born initially, not made" and their illnesses were exacerbated by the pressures of life. She attributed her own illness to a nerve disorder, but in her autobiography Cleaves lauded the benefits of "an environment, inviting content and happiness" and lamented that many of her own stresses in life came from attempts to be a caregiver, "with no one to look after me." ${ }^{31}$

Cleaves's autobiography testifies to the cultural ideal of home even as it acknowledges the paradoxical relationship between home and work in her own life. Her Autobiography of a Neurasthene (1910) looks back fondly on her childhood in Iowa, describing the health and sunshine of Iowa as a "pioneer land" and nostalgically pining for a return to that "simple life." But she also identifies her brother's and father's deaths as sources of

31. Nancy M. Theriot, "Women's Voices in Nineteenth-Century Medical Discourse: A Step Toward Deconstructing Science," Signs 19 (1993), 12, 15; Margaret Abigail Cleaves, The Autobiography of a Neurasthene (Boston, 1910), 18, 20, 46. For biographical information on Cleaves, see, in addition to her Autobiography, Constance M. McGovern, "Doctors or Ladies?: Women Physicians in Psychiatric Institutions, 1872-1900," Bulletin of the History of Medicine 55 (1981), 88-107; Sharon E. Wood, The Freedom of the Streets: Work, Citizenship, and Sexuality in a Gilded Age City (Chapel Hill, NC, 2005), 61-62; and Des Moines Register, 7/16/ 1880. Cleaves's hiring was part of a trend on the part of psychiatry to combat the growing influence of obstetrics, a feminized field that was also seeking to legitimate professional authority through medicalization and the use of hospital treatments and surgeries. The majority of women at asylums had always been diagnosed with "female problems" thought to stem from childbirth, menstruation, and "hysteria." These common diagnoses meant that psychiatrists might lose authority over patients to the fields of gynecology and obstetrics, and one response by state asylums was to hire female physicians as part of their staffs to supervise treatment of "female" problems and to preserve psychiatry's interest in the mental health of women. See Theriot, "Women's Voices." 
early psychic distress, along with what she saw as her mother's role and her own: "but after all what is woman's life, - whether wife mother or that of a doctor — but watching and waiting." Her autobiography does not specifically mention her time at the Mount Pleasant asylum, but she traces her own neurasthenic condition to the pressures of her work life and her inability to find rest even at home. She notes that at about the time she opened her private practice (in Davenport), "My environment had reached a degree of supersaturation with the pains and problems of life." While Shelton seemed to find comfort and direction in her work at the hospital, Cleaves, who was clearly passionate about her work, nonetheless lamented her inability to make her home a space free of work-related concerns. Cleaves clung to an ideal of home as a refuge from work, even as she acknowledged the centrality of her work to her very identity. ${ }^{32}$

For female patients, the asylum's distinct architecture may have represented medical and institutional answers to social and familial problems they faced at home. Women patients may have consented to surgical therapies as a method of birth control in an era when reliable birth control methods were illegal and unavailable. Likewise, asylums provided temporary relief for women suffering from emotional breakdowns in an era in which wife- and motherhood was idealized. The asylum's work and leisure spaces "enabled women with minor illnesses to recuperate in a way that was impossible when surrounded with the stresses of everyday life at home." Shelton mentions several women at the asylum who were plagued by anxieties about their children or homes - one always feared that her children were starving. In an era when home was where women were supposed to find fulfillment, the loss of home or children could be a cause of mental illness. A suicidal woman who attempted to escape the asylum in 1866 revealed to Shelton that "her home was burnt down \& all she had with it which caused her insanity. ... She has one of the saddest faces I ever saw." ${ }^{33}$

32. Cleaves, Autobiography, 33, 40, 56.

33. Theriot, "Women's Voices," 22; Terbenche, "'Curative' and 'Custodial,'” 46-47; Wood, "'My Life is Not Quite Useless,'” 11. 
Asylums like the one at Mount Pleasant may also have provided necessary spaces for long-term female patients who, in the migratory social landscape of nineteenth-century Iowa, may have had no family to care for them. The necessary "custodial" spaces of the asylum, then, may have been a response to changing patterns of mobility as well as to the very social shift they helped to produce: the movement of long-term caregiving responsibilities from home to institutions. Shelton notes at least one young girl at the asylum, being treated for "fits," whose "Mother is poor and cannot support her." Women like Cleaves and McCowen made their career choices in the midst of these transitions, for as unmarried women, both found themselves thrown upon their own resources for economic survival and chose to follow the movement of caregiving from home to hospital by becoming professionals. ${ }^{34}$

Shelton's diary, Cleaves's autobiography, and the concerns of women patients suggest a critique of home life as unable to provide healthy and empowering environments for women: both Shelton and Cleaves sought affirmation in their workspaces, and female patients sought relief at the asylum. But all also laud those traits traditionally associated with domesticity - rest, morality, healthfulness, and personal fulfillment - and lament the loss of those ideals in the homes from which they came. The asylum thus reflects, both in its architecture and in the ways individuals experienced that architecture, the conflicted relationship between domesticity and the institutional powers that sought to assume control over some aspects of private life in the mid- to late nineteenth century.

IN THE LATER DECADES of the nineteenth century, tensions between institutional authority and domestic ideology shaped debates over new design at the growing Mount Pleasant asylum. State and hospital authorities weighed the merits of a new form of asylum architecture on the rise in the 1870s and '80s generally called the cottage plan or system. The movement, underway in 1884 when the Iowa legislature appropriated more construction

34. Terbenche, "'Curative' and 'Custodial,'” 49; Wood, “'My Life is Not Quite Useless,'," 10. 
funds and began to debate the design of the asylum addition, allowed some patients to live and work apart from the main building in "cottages" that were more like the architecture of private homes than of public institutions. The combination of smaller buildings would be cheaper and suggested a community that lived, worked, and ate together in separate structures. In 1887 the AMSAII revised the Kirkbride propositions for the first time, rejecting some of the older principles in favor of this more modern but still "attractive and impressive" style. ${ }^{35}$ At the Mount Pleasant asylum, the selective adaptation of the cottage plan shows the continuing power of the domestic ideal, but suggests that the architectural ideal of the middle-class home could be embraced even as the asylum persisted in and even heightened its tendency toward the institutional goals that consolidated state authority.

This new style of architecture kept the old design principles such as classification, variation of activities, regulation, and pleasantness of surroundings, but the detached style and smaller buildings echoed the architecture of private homes and thus emphasized personal liberty and the integrity of individuals. The cottage style was influenced by nineteenth-century architectural trends that valorized the suburban family home. Doctors still worried that mental illnesses were bred at home, but they - and the culture at large - continued to idealize the rural cottage as an antidote to the trials of urban living, for the home was the place where "individuality takes its most natural and strongest development." Architects such as Andrew Jackson Downing regarded the rural cottage as an essentially American architecture, one that represented "the best character and pursuits, and the dearest affections and enjoyments of social life." In its revised propositions of 1888, the AMSAII presented a cottage design in which all of the buildings were in the Tudor or Stick style popular in larger resort homes of the era. The buildings offered a variety of symmetrical and asymmetrical designs, although the Stick style served to break up the surfaces of even the more rigidly symmetrical buildings (fig. 9). Where regularity was the rule in the Kirkbride plan, physicians now asserted

35. "Report of the Special Committee on Revision of the 'Propositions' of the Association," American Journal of Insanity 45 (1888), 56. 


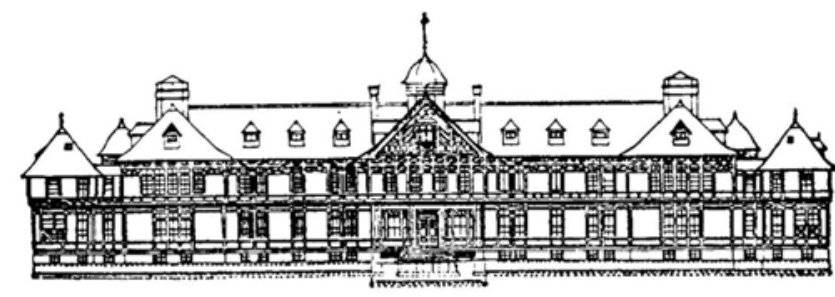

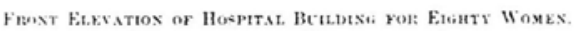
A MPLICATE OF THE HOSPTAL VOR MES

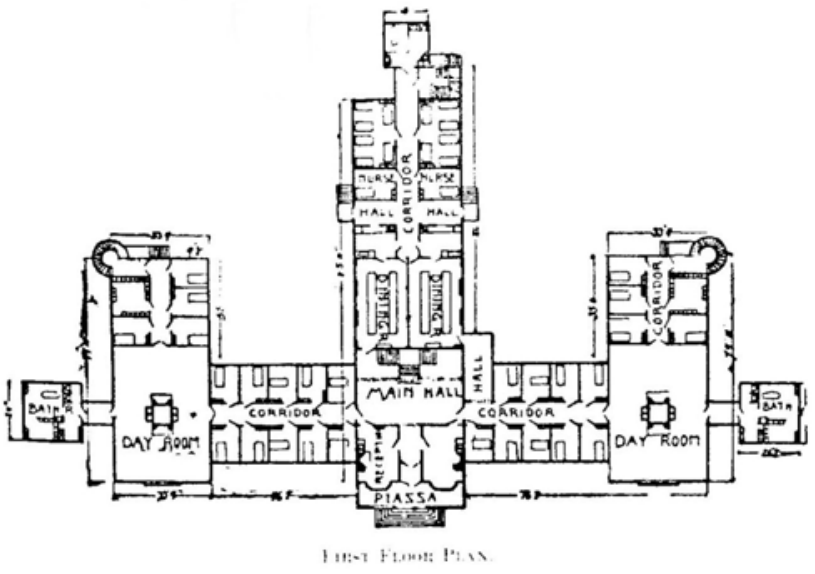

Figure 9. Plan for a cottage-style hospital building with Tudor or Stick styling. From American Journal of Insanity 45 (1888).

that the variety of the cottage system was the way to address the monotonous life "which is too often the type of the rural household, and which in so many instances begets mental disease among farmers and their wives." ${ }^{36}$

The adoption of the cottage plan at various state and public institutions in the decades after the Civil War was influenced by a number of factors. One was the attitude of physicians toward the growing population of "incurable" cases, which included the chronically ill, elderly suffering from dementia, and some-

36. A. J. Downing, The Architecture of Country Houses (1850; reprint, New York, 1969), xix, xx; Leland M. Roth, A Concise History of American Architecture (New York, 1979), 155; "The Colony System in Michigan," American Journal of Insanity 43 (1887), 577. 
times, the criminally insane. Under the doctrine of the moral cure, these cases needed to be permanently separated from those that were curable. Erecting separate buildings for such patients could, some physicians believed, make it possible to provide them with the care they needed while preserving the climate of cure for the curable so central to Kirkbride's linear plan. ${ }^{37}$

Moreover, by the last decades of the nineteenth century, the mounting opinion that insanity was hereditary among certain "classes" of citizens, particularly the poor and immigrant groups, influenced both physicians and the public to rethink the image of the asylum. Popular opinion emphasized the "palatial" architecture reminiscent of the European monarchy, which Mount Pleasant Superintendent H. A. Gilman saw as partly responsible for the classes of insane that overpopulated his asylum: "European countries becoming overwhelmed by the cries and demands of the defective, criminal, and mendicant classes, whose misfortunes and crimes are largely due to the grinding hand of a monarchial system of government, or the corrupt social system, born and nurtured in royalty, have sought a sewer for the elimination of these masses of corruption and decay." Sensational publications such as Elizabeth Packard's Modern Persecution; or, Insane Asylums Unveiled (1873), Francis Delilez's The True Cause of Insanity Explained; or, The Terrible Experiences of an Insane, Related by Himself (1888), and Nellie Bly's stunt reporting on her masquerade as a neurasthenic at Blackwell's Island in 1887 fueled perceptions of asylum architecture as less a country home than a Gothic palace that wrongly restrained the healthy, a dangerous world opposed to the home in which innocent men and women were taken away from their proper social roles and misdiagnosed as threats. Sensationalism suggested that the design of seclusion and central authority as well as the "Elizabethan" detailing of the structures themselves had been redesigned in the public mind. ${ }^{38}$

Superintendent Ranney recognized that public distrust of the asylum had its basis in the architecture that encouraged

37. Yanni, Architecture of Madness, 83.

38. Fourteenth Biennial Report (1888), 22; Jean Marie Lutes, "Into the Madhouse with Nellie Bly: Girl Stunt Reporting in Late Nineteenth-Century America," American Quarterly 54 (2002), 217-53. 
isolation and seclusion of patients and staff. In 1880 he wrote, "Within a few years there has been a good deal of clack and clamor in some quarters about the expense of maintaining the insane and the great cost of the palatial structures reared for this care." Several years earlier he had lamented that "the wards are all so nearly alike both in appearance of their constructive arrangements and furnishings ... with its inevitable corridor and rows of rooms on either side; the patient going from one to another finds little else than to live, perhaps a rather dreary monotony of sameness that gives no relief"; there was "little of that variety of form, furnishing, occupation, diversion [or] inducements to self-control." He granted that some asylums were too ornamental, referring to them as "grand piles of brick and stone," and went on to suggest that taste need not be sacrificed if large buildings were no longer the norm: the "simple break of outlines and inexpensive groupings, may be as pleasant as the most ornate and ambitious architecture." ${ }^{39}$

For mental health professionals such as Superintendents Ranney and Gilman, design was becoming less important as mental illness itself was pathologized. Physicians' efforts to remedy mental illness increasingly focused on the architecture of the brain rather than the architecture of the asylum; they attributed mental effects more often to lesions on the brain and to inherited illness. Psychiatrists sought to define themselves more narrowly as medical specialists rather than as possessing broader knowledge and skills - architectural, supervisory, and medical. Moral causes were relegated to the background as nutritional deficiencies, nerve disorders, and cerebral anomalies became the focus of attention and helped physicians legitimate their authority through new medical technologies rather than through the technologies of the asylum itself. Accordingly, Superintendent Gilman's biennial reports used photography to include images not only of the buildings' interiors but also photographic images of the diseased brain.

The emphasis on separate buildings and domestic styling also reflects trends evident in other public institutions at the time. College campuses, for example, like cottage-style asylums,

39. Eleventh Biennial Report (1882), 40-41; Ninth Biennial Report (1878), 33. 
began to use detached dormitories and strove to inculcate civic principles in their populations. Institutions meant to reform "deviant" classes also emphasized domestic living as a way to teach inhabitants the virtues of citizenship: model homes for immigrants and boarding schools for African Americans and American Indians also incorporated cottage-style dormitories and buildings in the belief that domestic work and arrangements fostered ideals of cleanliness, discipline, cooperation, and self-policing essential to citizenship. Such institutions suggested the loving environment of home even as they aimed to indoctrinate unruly or un-American "others" into civic life in more rigid and systematic ways than the family home ever could. ${ }^{40}$

The joint committee of the Iowa General Assembly that visited Mount Pleasant in 1884 to assess its needs pressed for "the erection of detached cottages, on the score of safety, economy, and sanitary reasons." This "outside" group supported the new plan, regarding the older tradition of building colossal structures as passé. Unlike early descriptions of the hospital that praised its technology, advanced sanitary systems, and sophisticated system of care, the committee now suggested that patients would do better in more homelike conditions and that the scale of the central building was actually a detriment to cleanliness and care. ${ }^{41}$

In a move that displays ambivalence about the cottage plan's more diffuse forms of control as well as struggles between state authorities and asylum leaders, the trustees ignored the committee's move toward modernity and instead requested funds to build extensions onto the existing wings of the hospital to house more than 300 patients. The additions were large - 120 feet long and four stories high - and exceeded the allotted expense. Chicago architects Willett and Pashley - who had previously designed an asylum at Kankakee, Illinois, that combined the cottage system with a linear hospital — worked under Gilman to complete, by 1887, the east and west wings that turned the institution into a sprawling expanse (fig. 10). In this case,

40. See Yanni, Architecture of Madness, 79-104.

41. Report of the Joint Committee of the Twenty-first General Assembly of the State of Iowa, Appointed to Visit the Hospital for the Insane Located at Mount Pleasant (Des Moines, 1886); Wesley Shank, The Iowa Catalog: Historic American Buildings Survey (Iowa City, 1979), 19. 


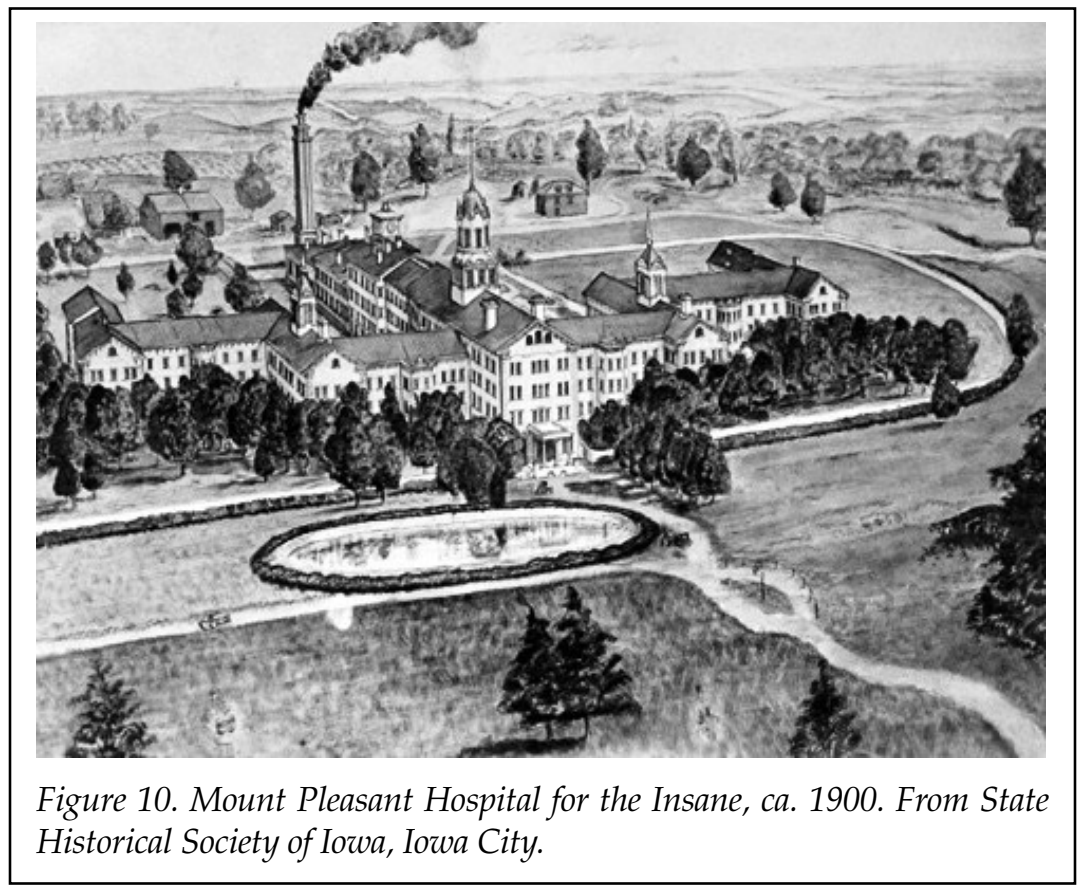

Gilman and the trustees seem to have won the struggle to preserve the authority of the superintendent to supervise patients, which many asylum physicians believed would be too difficult to maintain in the cottage system. ${ }^{42}$

Nonetheless, Gilman did make some concessions to the cottage system, especially when it came to community outreach. In 1890 an amusement hall was built at the back of the center building. It was meant not only for the entertainment of the patients but also for the local community to benefit from the concerts, lectures, dances, and "magic lantern" shows held here. In 1894 an industrial building for men was built, and in 1896 appropriations were made for infirmaries for aging men and women who had "helped change the state from a wilderness to a garden" by building homes and schools and fighting the Civil War (fig. 11). The Mount Pleasant asylum became a hybrid sort of construction, combining the original building's monumental expanse with smaller, more homelike yet just as specialized

42. Shank, Iowa Catalog, 19; Yanni, Architecture of Madness, 90-95. 


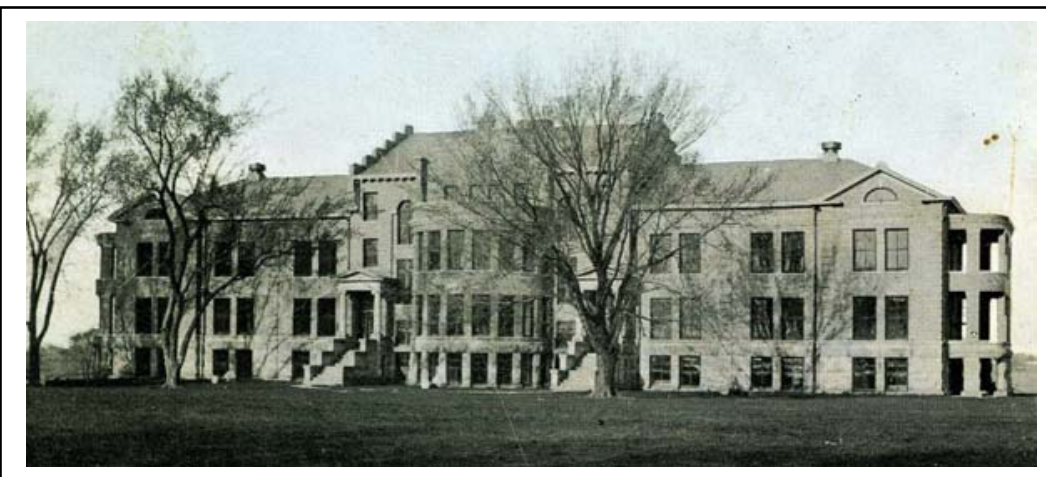

Figure 11. Ladies' Infirmary, Mount Pleasant Hospital for the Insane, ca. 1900. Postcard courtesy Iowa Wesleyan College Archives.

spaces for long-term, aged patients not expected to recover. The mixed architecture present on the Mount Pleasant asylum grounds by the turn of the century echoes changes in the ways patients were being categorized: the older building suggests an understanding of mental illness that emphasized environment and used design to classify and control patients; the newer, segregated buildings show how "homelike" design could become a patina on more systematic and statistical ways of evaluating and categorizing patients. ${ }^{43}$

In 1898 the legislature established a new State Board of Control of Institutions, which signaled the consolidation of state control and the loss of Gilman's independence as a designer. The move served to separate the roles of architect and physician that the superintendent had once simultaneously embodied. The board of trustees was abolished and replaced by the Board of Control, which oversaw a variety of state institutions, including prisons, reform schools, and homes for the blind and deaf. The new board made decisions about plans, materials, architects, and labor and was also responsible for collecting statistics about the populations served by the institutions. ${ }^{44}$

The mixed design of the institution at the turn of the century reflects other ways that the Mount Pleasant facility may

43. Yanni, Architecture of Madness, 89.

44. Shank, Iowa Catalog, 22-24; Nineteenth Biennial Report (1898), 8; Seventeenth Biennial Report (1894), 9-13. 
have been struggling with transitions to more modern, statistical ways of viewing citizens. In 1899 the American Statistical Association praised the new Iowa State Board of Control for its "exhaustive" statistical tables of all inhabitants of state institutions. The "model document" organized patients according to race, nativity, "hereditary tendencies," and more precise categories of employment, among others. One exception, however, was the Mount Pleasant asylum, which still categorized 90 percent of its female patients as "domestics," not recording the occupation of the head of her family, which statisticians believed would provide a more accurate understanding of the "social environment" from which she came. While the leaders of the Mount Pleasant asylum were moving towards less architectural and more categorical ways of approaching mental illness, there may have been a lingering sensibility that home as a defining social force still had valence. ${ }^{45}$

The conflicts over and selective use of the separate structures at Mount Pleasant show concurrent ways of thinking about the relationship between homes and institutions. The original asylum appeared to be homelike in the values it inculcated in its patients, but its monumental and systematic architecture distinguished it from the homes that were believed to have instigated the problem in the first place; it used design to define deviance and control patients' bodies through specialized rooms and organization. The cottage system symbolized a reversal of that view: While the structures appeared homelike, systems of order prevailed within, treatment was increasingly medicalized, and authority operated at a farther remove, shifting from the superintendent to the State Board of Control. As the cottage system came to prevail in the early twentieth century, more domestic forms of architecture were accompanied by more diffuse and systematic forms of control represented by statistics and professional medical authority. Structures that physically separated genders and coded spaces in terms of treatment, work, and leisure activities increasingly were replaced by bureaucratic structures that codified patients by form of illness, class, race, and gender. ${ }^{46}$

45. C. E. A. Winslow, "Review: Statistics of Institutions," Publications of the American Statistical Association 7 (September 1900), 35-37.

46. Yanni, Architecture of Madness, 103; Erica Lilleleht, "Progress and Power," 178. 
THE STORY of the Mount Pleasant asylum is in many ways a familiar one to historians of mental health: ambitiously constructed at mid-century, by the turn of the century the structure was deteriorating, overcrowded, and undergoing a shift from the central, localized authority of the superintendent to the bureaucratic control of the state. The sprawling asylum continued to operate until 1936, when a fire destroyed most of the original building. But the history of the asylum is more than a story of the literal rise and fall of a particular type of architecture; instead, the asylum's design responded to struggles within the society of nineteenth-century Iowa itself to understand the meaning of home, work, gender roles, domestic virtues, and institutional authority even as it created new situations, relationships, and interactions that affected the public, asylum workers, and patients alike. The metaphor of home and family so often invoked by administrators was not just an allusion to a simple ideal; the conflicted meaning of "home" as an incubator for social life and as a physically and socially flawed space invests this comparison with historical value. The history of the Mount Pleasant asylum reveals ways that public architecture exists in close relationship with understandings of the benefits and limits of domestic space. Even as superintendents attempted to reassure officials, families, and patients that the building's design would provide homes for the needy, the intention was to impress citizens with its difference from domestic architecture and the relationships that, to their minds, often caused disorder. And while the building's spaces reinforced nineteenth-century domestic values, such as separation of spheres, central authority, and moral self-control, the design of the asylum and the experiences of workers and patients implied a critique of home life that ultimately was part of larger movements toward institution-building and professionalization in the late nineteenth century. ${ }^{47}$

47. Today, the Mental Health Institute and the Mount Pleasant prison facility occupy the site of the original Mount Pleasant asylum. 